\begin{tabular}{|c|c|c|c|c|c|c|}
\hline \multirow{4}{*}{ Impact Factor: } & ISRA (India) & $=3.117$ & SIS (USA) & $=0.912$ & ICV (Poland) & $=6.630$ \\
\hline & ISI (Dubai, UAE & $=0.829$ & РИНЦ (Russia & $=0.156$ & PIF (India) & $=1.940$ \\
\hline & GIF (Australia) & $=0.564$ & ESJI (KZ) & $=8.716$ & IBI (India) & $=4.260$ \\
\hline & JIF & $=1.500$ & SJIF (Morocco & $=5.667$ & OAJI (USA) & $=0.350$ \\
\hline
\end{tabular}

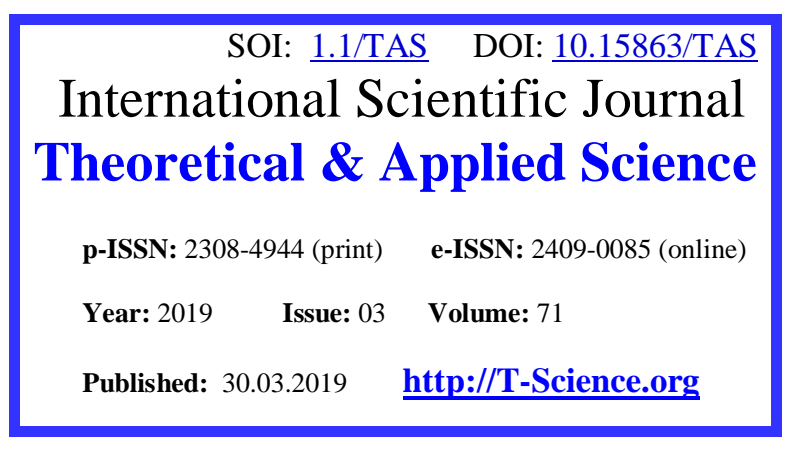

SECTION 13. Geography. History. Meteorology. Oceanology.
QR - Issue
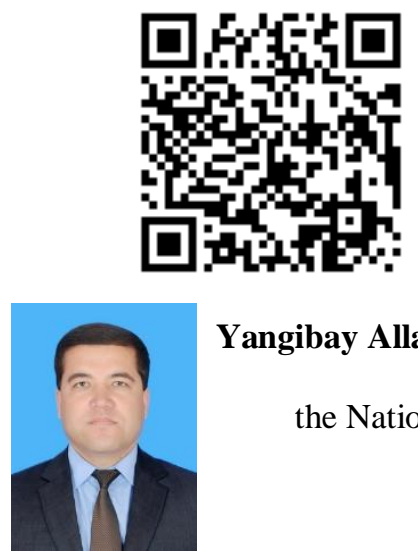

QR - Article

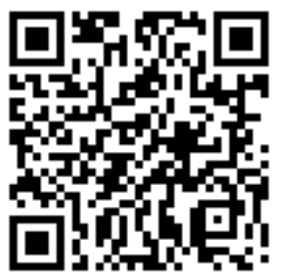

Yangibay Allamuratovich Turdimuratov Independent researcher of the National university of Uzbekistan named after Mirzo Ulugbek new rich80@mail.ru

\title{
NATIONAL VETERINARY MEDICINE IN TRADITIONAL UZBEK LIVESTOCK BREEDING
}

Abstract: This article analyzes the methods of treating various diseases of livestock by illustrating national veterinary science of Uzbek livestock owners, who have long years of rich experience and observation based knowledge and methods, used for the treatment of livestock for many years.

Key words: traditional cattle breeding, cattle-farmers, national veterinary medicine, livestock diseases, experiments, methods, healing herbs, infusions.

Language: English

Citation: Turdimuratov, Y. A. (2019). National veterinary medicine in traditional Uzbek livestock breeding. ISJ Theoretical \& Applied Science, 03 (71), 468-471.

Soi: http://s-o-i.org/1.1/TAS-03-71-41 Doi: crosłef https://dx.doi.org/10.15863/TAS.2019.03.71.41

\section{Introduction}

Livestock breeding is one of the main and most ancient forms of economic activity in Uzbekistan. In Uzbekistan, particularly in the south of Surkhandarya, the population has been engaged in cattle raising since ancient times. According to archeological researches conducted in the area, during the Bronze Age, livestock farming grew up in the area, mainly feeding small cattle livestock [1, p. 7]. The healthy state of livestock played an important role in lives of farmers and peasants. So they sought to cure the infected livestock not only through "magic" activities (praying, turning around the grave, passing through the fire, etc.), but with the help of the centuries-old experience and observations, the knowledge of national veterinary medicine.

Traditional national veterinary medicine has not yet been studied as a separate research object in the historical and ethnographic aspect. Therefore, by studying national veterinary medicine, we can identify the long standing rich experience of our people in the treatment of livestock. As it is commonly known, modern veterinary medicine is a fundamental factor in the development of livestock, therefore livestock raising could not exist without public veterinary.

Since ancient times, human beings have founded a national veterinary medicine, by treating not only people, but also taking care of and curing pets.
According to the information, the emergence of the national veterinary service dates back to the ancient times, when human beings started to domesticate animals which had influence on their development and reproduction.

\section{Materials and Methods}

The development of national veterinary medicine is associated with the development of pottery, giving people the opportunity of making a medication for the treatment of people and livestock in pottery products. The author of "Canon of Medicine" by Abu Ali ibn Sina (980-1037), who made a great scientific contribution to the development of pathology, pharmacology and pharmacopeia, served as a basic guide not only for medicine, but also for veterinary staff for five centuries. Until the first quarter of the $20^{\text {th }}$ century, there was almost no veterinary and zoo related technical service in the Bukhara Emirate. In 1910, there was only one veterinarian in the Emirate. In 1912, two veterinary departments were established in Bukhara and Karshi, and they served only nearby area [6, p. 89]. In addition, people with a great deal of knowledge on the national veterinary science, which was based on centuries-old folk experience and observations, were rare. Therefore, livestock breeders tended to use traditional methods inherited from the ancestors in the 


\begin{tabular}{|c|c|c|c|c|c|c|}
\hline \multirow{4}{*}{ Impact Factor: } & ISRA (India) & $=3.117$ & SIS (USA) & $=0.912$ & ICV (Poland) & $=6.630$ \\
\hline & ISI (Dubai, UAE & $=0.829$ & РИНЦ (Russia & $=0.156$ & PIF (India) & $=1.940$ \\
\hline & GIF (Australia) & $=0.564$ & ESJI (KZ) & $=8.716$ & IBI (India) & $=4.260$ \\
\hline & JIF & $=1.500$ & SJIF (Morocco & $=5.667$ & OAJI (USA) & $=0.350$ \\
\hline
\end{tabular}

treatment of infected and diseased cattle. In the past, there were no special medicines for the treatment of animals. For this reason, remedies were prepared from herbs and healing plants. Shepherds, for example, were able to treat illnesses in the sheep with various herbs and useful plants, to treat wounds, by feeding them with healing herbs, removing infectious worms out, putting some particular herbs on diseased or infected parts of animal body, washing them and greasing them. People used to remove the thorns from the ears of livestock one by one, gastrointestinal and other internal diseases were treated with various herbs (especially incense - paganum harmala) and their tincture [4, p. 112].

Uzbeks who have been engaged in cattle breeding since ancient times had extensive experience in pet care. If animals are exposed to the spread of infectious diseases such as anthrax, smallpox or plague epidemic causing severe skin ulceration or a form of pneumonia, they quickly changed the pasture to feed the cattle or slaughtered the affected animals and burned the skin to prevent the spread prevent the spread of notifiable infection that can be transmitted to humans [3, p. 54]. Deceased animals were buried deep in the ground. In the case of the spread of bovine papular stomatitis or diphtheria in livestock, the crushed powder prepared from the mixture of nutritional salt and copper syrup was greased into the animal's mouth cavity and tongue. Itchy skin disease of cattle was treated by washing several times using tinctures from the roots of poisonous plants or kerosene. In the past, livestock breeders were watching a variety of animal diseases, depending on the season. For example, when sheep were to give birth (calving season), a white disease was observed, which means that wounds appeared on sheep udders and consequently sheep's milk flow stopped. Then, infected milk was absorbed into the entire body of the sheep and eventually died. The lambs that could not get her milk began to die one by one. In order to prevent the illness, people used a bird like sparrow hawk in size and shape, no light on his head, dark bird with red beaks. They used to dry the bird under hot sunrays then put it into the glowing embers and immediately to the udders of sheep [8].

Shepherds prepared specific herbal remedies in case of outbreak of particular diseases such as bovine worm and intestinal worm. To do this, people ground the branches and leaves of healing trees (viburnum vulgaris) in the mountains, boiling them well in the water. After long hours of boiling, flesh part of the tincture was extracted and liquid was given to every diseased sheep to drink [9]. If the sheep have a black lung disease, the crushed cattle lungs are placed on the sick sheep's ears and the process followed by pressing with heated wire on the ears. In case of the disease "Malla niyaz" (intestinal worm disease), the sheep were left hungry for a day and afterwards were fed with ferula. If lung worm was defined shepherds would make their sheep drink tincture of ferula. To carry out this, sheep throat was cut so that tincture could go into the lungs. People cured the sheep with mange or ringworm diseases, by applying ash of amygdalus spinossisima [8].

In the sheep and cattle there is a tendency to lame, ie "green". This disease occurs twice a year: in summer and winter, especially the disease was more dangerous in winter compared to other parts of a season. The herd diseased with the illness lame would be left separately throughout a plain without water even the weather was too hot. The cattle were made to wander around the plain until they were exhausted and their mouths were dried up [10]. The cattle diagnosed with this disease were also given hot bread. The illness lame turned up in winter was difficult to treat because of bad and cold weather conditions. They used to be always kept in dry places. The cattle that had been damp on their feet would be definitely dead [11].

Shepherds also prepared special medicine remedy from sheep manure and it was called "kiypovi". To do this, the dried manure was burnt in a pit on the ground. Something was put to block the mouth tube of the pit, as a result, it generated moisture and that liquid was applied to the itching and wormy sheep. Because the ointment gave off a bad smell mosquitoes or other insects would not go to the animals. However, the animals with small horns used to be exposed to plague. In such cases, they would bring water (black in color) from the Khojaipok ota pilgrimage located in Yangiyer village of Sherabad district of Surkhandarya region. The water used to be applied to the entire bodies of the cattle [12].

In the Zarafshan Oasis, livestock owners would spray water from mouth to mouth of the cattle when they began to baa heavily. To do this, an experienced person was invited to take some water from a pitcher to his mouth and spray it into the mouth of the sheep. This would mostly help stop baaing. If the sheep was diagnosed with sheepskin they would always be butchered and their skin used to be burnt in order to prevent its spread [5, p. 67].

Special herbal juice (glue-like) was applied to cure itching in goats. When the spleen was inflamed, their ears were pierced and if they bled, it meant that they must have recovered. They tried to treat the injured sheep by using simple methods. For example, the hot skimmer was pressed onto the part of a body, which a wolf bit and a piece of felt was stuck on the wounded part. The felt applied would help the wounded skin to recover faster than normal process. The shepherds were expected to kill the sheep immediately which were not able to walk correctly because of physical injury to or weakness in the legs or feet. Occasionally, a broken lamb leg was tied with a stick [13].

There were such cases when many livestock died in a short span of time due to infectious diseases. According to old and skilled shepherds, if 100-150 


\begin{tabular}{|c|c|c|c|c|c|c|}
\hline \multirow{4}{*}{ Impact Factor: } & ISRA (India) & $=3.117$ & SIS (USA) & $=0.912$ & ICV (Poland) & $=6.630$ \\
\hline & ISI (Dubai, UAE & $=0.829$ & РИНЦ (Russia & $=0.156$ & PIF (India) & $=1.940$ \\
\hline & GIF (Australia) & $=0.564$ & ESJI (KZ) & $=8.716$ & IBI (India) & $=4.260$ \\
\hline & $\mathrm{JIF}$ & $=1.500$ & SJIF (Morocco & $=5.667$ & OAJI (USA) & $=0.350$ \\
\hline
\end{tabular}

sheep out of 1000-1200 die, the rest, which were healthy, could be able return to summer fields being fed well. Thus, 10 percent loss was not that dangerous for the shepherd and the cattle. There is a public statement: "The cattle catches up the cattle in 4o years". It states that if animals died of a variety of natural disasters or diseases, their recovery would usually take a long time [7, p. 19].

If milk does not come out of the cow's udder after giving birth, using incense is a great deal and the most practical measure to handle. They prepared a special watery dish from wheat or barley and made the cow drink. If there was a loss of appetite and loss of weight, it was diagnosed as having a "mite". In this case the cow was made to drink raw cotton oil or round shaped dough balls were put on the back part of a cow, pelvic bone (upper part of its tail). The cotton oil causes temporary diarrhea, cleans the stomach as well. As a result, it would give an appetite, then, because of proper eating they would totally recover [14].

The cattle consumed poisonous plants and herbs, which might be found upper meadows in the mountains, would usually die. Even horses poisoned by those poisonous plants could not walk. Poison prevented its joints to be bent, as well as could harm digestion through damaging intestines. In such emergency situations the animal was made even forced to eat rock salt (animal salt) or drink remaining water from sour milk. After that, the horse was wrapped in a felt and ridden. The horse was initially sprouted, and when it was hot, it would sweat and the joints would begin to bend. Consequently, the horse used to urinate and next stage would be diarrhea. In this way, the horse would get rid of "poisoning" and recovered.

If the horse was unable to walk or move in a normal way during a journey, they thought it was a blister, a painful red swelling on the skin that contains liquid. Horse's leg was tied with a red thread. A blue rope is tied when the wound appears on the foot. Most of the horses were healed by letting the blood out. If these measures did not work, they would address to mullahs (an Islamic religious teacher or leader) or go to a cemetery [4, p. 94]. That is to say, they tried to treat this disease by means of "magic" actions (praying, turning around a grave). One of the usual diseases in the horses is the wound - "jaur" (the term jaur - also spread among the Russians living in Central Asia and Kazakhstan). It was caused by the fact that the wooden base was not properly positioned and was not arranged correctly. The disease "jaur" was treated in the following order: the mushroom pollen was smashed into the wound or the base of the stem of a newly cut healing plant - ferula. Other herbs were also applied to wounds. Usually, injuries at shoulders causes edema or swelling. To prevent the swelling from getting into the wound, they also pressed the heated piece of cloth, dried and hot calfdung, or lamb skin [4, p. 93-94].

The common method of treating many domestic animals in the area was to get blood. Sometimes they tried to cure the animal by cutting off the tail or the cartilage in the nasal cavity, as well as applying some healing tinctures and oil used formerly for carts[15]. An oily herbal remedy for various animal diseases in Turkmenistan was "innev" (oily herb). It looks like sesame having similar seeds to sesame seeds. "Innev" was considered as wild plant and it was grown for special purposes. After it had grown fully, the whole plant was pulled off together with its trunks and then was dried. After that, seeds used to be withdrawn and were used to produce oil (black oil). It was poured into the nostrils of the camel and then forced the camel to walk carrying heavy loads of things. If a camel had sweat, it would have thought to get probably recovered. The method was considered beneficial for its practical outcomes and was used for lung infections of the cattle [2, p. 227].

If swollen bruises that look like pillows appear, to cure it people usually added salt to the sour milk and applied the mixture to the swollen area, and afterwards peeled reed was tied up tightly over the swelling. In case of many warts in horses, sour milk was applied to the warts and the area was licked by dogs intentionally [14]. Lakays (an Uzbek nation) used several methodxs in practice to eliminate warts in horses: cutting, burning, tying tightly up to the deep end of its leather [15].

\section{Conclusion}

To conclude, keeping livestock breeding in the past has led not only the cattle breeders to know their ways of feeding them, breeding them, but also gaining knowledge of the phenology, and providing veterinary care to the sick animals. Due to the lack of veterinary and zoo related technical service, national veterinary medicine that suggested various methods of treatment based on centuries-old experience of keeping livestock was of great importance and people relied on it. People's veterinarian knowledge had been inherited from generation to generation, and specific traditions have been developed, believed and firmly followed by people. 


\begin{tabular}{|c|c|c|c|c|c|c|}
\hline \multirow{4}{*}{ Impact Factor: } & ISRA (India) & $=3.117$ & SIS (USA) & $=0.912$ & ICV (Poland) & $=6.630$ \\
\hline & ISI (Dubai, UAE & $=0.829$ & РИНЦ (Russia & $=0.156$ & PIF (India) & $=1.940$ \\
\hline & GIF (Australia) & $=0.564$ & ESJI (KZ) & $=8.716$ & IBI (India) & $=4.260$ \\
\hline & JIF & $=1.500$ & SJIF (Morocco & $=\mathbf{5 . 6 6 7}$ & OAJI (USA) & $=0.350$ \\
\hline
\end{tabular}

\section{References:}

1. Annayev, T., \& Shaydullayev, S. (1997). Surxondaryo tarixidan lavhalar. (p.7). Tashkent: Fan.

2. Babadjanov, R. (1975). $K$ voprosu o skotovodcheskom xozyaystve turkmen Tedjenskogo oazisa v konse XIX - nachala XXvv. Xozyaytsvenno-kulturniye traditsii narodov Sredney Azii i Kazaxstana. (p.227). Moscow: Nauka.

3. Jabborov, I. M. (2008). O'zbeklar (an'anaviy xo'jaligi, turmush tarzi va etnomadaniyati). (p.54). Tashkent: Sharq.

4. Karmisheva, B. X. (1954). Uzbeki-lokaysi Yujnogo Tadjikistana. Vip.1. Istorikoetnograficheskiy ocherk jivotnovodstva. (p.112). TIIAE AN TadSSR, Stalinabad.

5. Toshev, X. (1972). Traditsionnoye jivotnovodstva uzbekov Srednego Zarafshana. Etnografichekoye izucheniye bita i kulturi uzbekov. (p.67). Tashkent: Fan.

6. Shaniyazov, K. (1973). Otgonnoye jivotnovodstva u uzbekov. Ocherki po istorii xozyaystva narodov Sredney Azii. (p.89). L.: Nauka.

7. O`zR, F. A. (1830). Alisher Navoiy nomidagi Til va adabiyot instituti folklor arxivi. Inv. 1830/1. p. 19.

8. (2007). Surxandarinskiy oblast Djarkurganskiy rayon seleniye Ismailtepa. Poleviye zapisi.

9. (2010). Surxandarinskiy oblast Baysunskiy rayon seleniye Sariasiya. Poleviye zapisi.

10. (2008). Surxandarinskiy oblast Baysunskiy rayon seleniye Kafrun. Poleviye zapisi.

11. (2007). Surxandarinskiy oblast Kumkurganskiy rayon seleniye Yangiyer. Poleviye zapisi.

12. (2006). Surxandarinskiy oblast Kumkurganskiy rayon seleniye Jalair. Poleviye zapisi.

13. (2007). Surxandarinskiy oblast Kumkurganskiy rayon seleniye Arpapaya. Poleviye zapisi.

14. (2007). Surxandarinskiy oblast Kumkurganskiy rayon seleniye Xujamulki. Poleviye zapisi.

15. (2010). Surxandarinskiy oblast Denavskiy rayon seleniye Jartepa. Poleviye zapisi. 